DOI: https://doi.org/10.34069/AI/2022.49.01.24

How to Cite:

Dudareva, M.A., Morozova, S.M., Mirzoeva, R.M., Aripova, D.A., \& Bronnikov, D.G.. (2022). National axiology of A. M. Zhemchuzhnikov's poetry. Amazonia Investiga, 11(49), 218-223. https://doi.org/10.34069/AI/2022.49.01.24

\title{
National axiology of A. M. Zhemchuzhnikov's poetry
}

\section{Национальная аксиология в поэзии А. М. Жемчужникова}

Received: October 12, 2021
Accepted: December 27, 2021

\author{
Written by: \\ Marianna A. Dudareva ${ }^{44}$ \\ https://orcid.org/0000-0002-4950-2322 \\ SPIN: 5362-0507 \\ Svetlana M. Morozova ${ }^{95}$ \\ https://orcid.org/0000-0003-2955-8545 \\ SPIN: 4093-9458 \\ Rimma M. Mirzoeva ${ }^{96}$ \\ https://orcid.org/0000-0003-3392-7470 \\ SPIN: 8907-8547 \\ Darya A. Aripova ${ }^{97}$ \\ https://orcid.org/0000-0002-4515-4834 \\ SPIN: 9624-3336 \\ Denis G. Bronnikov"8 \\ https://orcid.org/0000-0002-0382-4414 \\ SPIN: 6467-0780
}

\begin{abstract}
Аннотация
У каждого национального образа мира есть свои константы, коды. В космосе русской культуры одной из таких культурных единиц выступает дерево, воплощающее идею мировой оси. В данной статье обращаемся к поэтическому творчеству А. М. Жемчужникова, в поэтике которого напряженной семантикой и особыми функциями наделен древесный код. Подробно анализируем цикл «Сельские впечатления и картинки», который составляет литературный материал для онтогерменевтического анализа. Целью статьи выступает выявление национальной аксиологии, а именно древесного кода в русской поэзии. Объектом исследования является национальная топика. Предметом принципы проявления древесного кода в творчестве поэта XIX века.

Методология исследования сводится к целостному онтогерменевтическому анализу, направленному на высвечивание
\end{abstract}

\footnotetext{
${ }^{94}$ Candidate of Philology, docent, Russian Language Department No. 2, Institute of the Russian language, RUDN University, Russian Federation.

${ }^{95} \mathrm{PhD}$ of pedagogical sciences, docent of the Department of Russian and Foreign Languages. Sergio Ordzhonikidze Russian State University for Geological Prospecting, Moscow, Russian Federation.

${ }^{96} \mathrm{PhD}$ of pedagogical sciences, docent of the Department of Russian and Foreign Languages. Sergio Ordzhonikidze Russian State University for Geological Prospecting, Moscow, Russian Federation.

${ }^{97}$ Irkutsk National Research Technical University, Irkutsk, Russian Federation.

${ }^{98}$ The Kosygin State University of Russia, Moscow, Russia.
} 


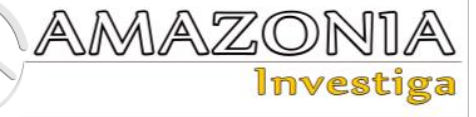

otherworldly paradigm, the search for "another kingdom". The research results are to identify the cultural potential of the poetry cycle for the further study of the national topic, national existence and otherness, apophatics as a phenomenon of Russian culture associated with the phenomenon of death. The results of the work can also be used in teaching courses in Russian literature, cultural studies, philosophy.

Keywords: transmission of culture, wood, world axis, folklore, poetry.

фольклорной, этнографической парадигмы данного поэтического цикла. Уделяется большое внимание мифологеме пути-дороги. Проводятся параллели с русской волшебной сказкой, для которой характерна иномирная парадигма, поиск «иного царства». Результаты исследования заключаются в выявлении культурного потенциала поэтического цикла для дальнейшего изучения национальной топики, национального бытия и инобытия, а также апофатики как феномена русской культуры, сопряженного с феноменом смерти. Результаты работы могут быть использованы в преподавании курсов по русской литературе, культурологии, философии.

Ключевые слова: трансмиссия культуры, дерево, мировая ось, фольклор, поэзия

\section{Introduction}

Each researcher of culture thinks about the question of national identity, the national image of the world, which allows him not to lose his roots and build a vertical transmission of culture. In the Russian version of being, one of the main elements is literature, since it is one of the first to transmit cultural meanings. Literature in Russia is closely related to folklore. Folklore conveys to literature the ethical and aesthetic ideal of man, through traditional art we get to know the national axiology.

Each national image of the world, or CosmoPsycho-Logos, in the language of the famous philologist and culturologist G. D. Gachev, has its own constants, "a priori", that form a national axiology. In Russia, the nature, the plain, has the qualities of an apeiron, a limitless particle in the concept of Greek philosophy, since the Russian plain embodies the horizontal axis of the world. For these reasons, natural realities that organize the Cosmos and determine the Logos are important for a culturologist, and among them is a tree (the Axis of the World). Gachev writes: "... in Russia, Poland, Germany, plant symbols prevail: forest, tree, grass, leaf, color, grain" (Gachev, 2008, p. 21). Through these constants, we can form an idea of the national image of the world. The special connection between man and tree in the Russian Cosmo-Psycho-Logos has long been pointed out by Russian poets. So, S. A. Yesenin in the philosophical treatise "The Keys of Mary" (1918) writes about the origin of music, ornament, embroidery and even man himself from a tree (the World Tree): "... The thought of this origin from the tree gave rise, along with music, to a mythical epic" (Yesenin,

1997, pp. 189-190). Modern researchers come to the idea of the cultural-philosophical significance of dendronyms, since they "have cultural potential, that is, they convey information about the relationship between man and nature, the worldview of the people, moral and spiritual traditions, express the experience of an ethnic group ..." (Abramova, 2019, p. 69). In Russian poetry of the early 20th century, according to A. A. Isakova, dendronyms have "not only a superficial, external, but also an internal, symbolic dimension" (Isakova, 2011, p. 3). However, tree essences (a concept from A. A. Isakova's dissertation) are also filled with such a symbolic sacred meaning in the poetry of the 19th century. Let us turn to the work of A. M. Zhemchuzhnikov, who this year marks the 200th anniversary of his birth.

\section{Materials and methods}

The progenitor of Kozma Prutkov, the author of a poem about cranes, from which a well-known camp song about the fatherland grew ("Here, under a stranger's sky, I am an unwelcome guest ..."), A. M. Zhemchuzhnikov went through an unusual path in literature - about his gentle, full of lyricism, love the poet's native nature, philosophical reflections on life, the contemporary critic and the reader learns in full quite late, since only at the end of his life the poet himself, at the urgent request of his daughters, publishes his poems (two-volume Poems, 1892). There are not very many articles and dissertations about the poet's poetry either, although, according to researchers, it was Zhemchuzhnikov's lyrical work that was "an 
important fact of Russian poetry in the second half of the 19th century, in which the traditions of G. R. Derzhavin, A. S. Pushkin, E. A. Boratynsky,

M. Y. Lermontov, N. A. Nekrasov, A. A. Fet" (Kapitonova, 2005, p. 3). However, Zhemchuzhnikov is not only a contemplator, admiring his native nature, enjoying rural life, as researchers often imagine him, analyzing the famous cycle "Rural Impressions and Pictures" (in two series), but also a thinker, ontologically showing a deep experience of changing moods, seasons of nature, day and night, light and darkness.

Let us turn, using the ontohermeneutic method, to a poetic cycle consisting of ten sketches, paying utmost attention to the image of the "path - the road" and the image of the rakita. Ontohermeneutic method, or cultural poetics, is that a work of art is placed in a ramified cultural and historical context, and the ontological plan of the work is put forward in the first place in the analysis. The parallel with Russian folklore, a fairy tale turns out to be productive. Russian verbal culture is characterized by the search for "another kingdom".

\section{Results}

In the first poem "In the carriage for Moscow", the lyric hero leaves Moscow, enjoying the view from the window:

Sweet nature! Oh, my dear land,

Precisely guarded by a host of quiet angels!

Having just said goodbye to city life,

I was left alone, surrounded by you,

And the spiritual burden - fears and anxieties Threw it out the windows along my road. (Zhemchuzhnikov, 1910, 150)

We see a complete detachment from the bustle of the city and unity with the cosmos of nature:

Dreams swarm lightly over me,

As if I was intoxicated with the intoxicated braga.

So the dusk is disappearing, there is coolness in the air ...

I don't think about anything, I don't need anything. (Zhemchuzhnikov, 1910, 151)

It is interesting how this poem ends - its last line is very apophatic: there is a temporary rejection of the mundane, even a thought does not bother the hero (a certain state of hesychasm, a formless mind), only he prays to nature, dissolving in it. But the road isn't so simple and unambiguous, and the intonations change in the second poem of the Rakita on the High Road cycle:

No, the heart, then, is not cold,

The taste has not become coarse over the years! What was cute before

I won't get enough of it now. (Zhemchuzhnikov, 1910, 151)

The heart worries, which remembers something, revives long-forgotten thoughts. But why is it worried?

I am especially captivated

This kind of peculiar

The roads are sad and silent

With its alleys wickets.

I figure them out

When I walk under their shadow;

And with them myself, in response to their noise, I have long conversations. (Zhemchuzhnikov, 1910, 151)

Here it is worth referring to the semantics of Rakita in the Slavic space. We all remember the lullaby about the gray top, in which the end is like this: it will drag the top under the broom bush. Of course, this lullaby reminds us of death - a child has just come to this world from that, he is still a borderline creature, not completely rooted in our world, and is associated with "that light" (it is no coincidence that the theme of death is the leitmotif in children's play folklore, see . game of the deceased). In addition, the motive of the child's motion sickness is associated with stable images and formulas: edge, bush, forest, wolf (Gorbunova, 2021). And the rakita is a border tree with a different semantics, like the willow and willow related to it (they are connected, as studies of folklorists show, with the formulas of the impossible (Agapkina, 2014, p. 291). And with Zhemchuzhnikov, the rakita accompanies the hero's path, which gradually turns into a path, reminding him of the past, of the important:

I figure them out

When I walk under their shadow;

And with them myself, in response to their noise, I have long conversations.

They are branchy and powerful,

They tell me about the old days;

About whirlwinds, thunderclouds,

Snow, blizzard, crackling frost

And a long series of happy days. (Zhemchuzhnikov, 1910, 151)

The poet spent his childhood on his father's estate in the Oryol province, bordering on the Voronezh province, in the onomasticon of which the 


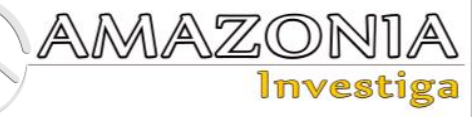

lexemes "rakita", "vetla", "willow" are frequent (Syanova, 2010: 85). But the point, of course, is not so much in biographical facts, the poet should not be taken to an oath of fidelity to reality, as in the poetic and even archetypal tradition, in the "tree code" of Russian literature. Vetla with the semantics of the otherworld is first encountered by V. A. Zhukovsky in "The Forest Tsar", then with the same meaning - by A. P. Chekhov in "The Steppe" and I. A. Bunin in "The Life of Arseniev" (Dudareva, Goeva, 2017), but these remarks require an extensive culturological, even cultural-philosophical study of the "tree code" of Russian literature, and our goal was to outline the paths-roads to this World Tree, from which our song, music and word originate.

Wood thoughts are a characteristic epithet combination for the Russian Cosmo-PsychoLogos (our nature, our traditions and rituals, in which wood is often involved, our poetry). Everything from wood, music and ornament, will be written by Yesenin in 1918 in the treatise "The Keys of Mary". Our folk music with its tragedy and message to death - also from a tree, from a reed cut by a shepherd: "The origin of music from the tree in our mysteries is the most beautiful key in our hands from the doors of the closed temple of wisdom. Without Jovull and Weinemeinen, our people, through the simple face of a nameless shepherd, revealed two hidden forces of air together. This shepherd did nothing but cut a reed at the grave, and it was not he, but she herself who told the world through him her magic secret: "Play, play, shepherd boy. Pour out my evil sadness with sounds. You are not holding a simple pipe in your hands" (Yesenin, 1997, p. 190). But Zhemchuzhnikov, as it were, anticipates these theoretical folklore discoveries of Yesenin. The lyrical hero of "Rural Impressions and Pictures" learns from nature, the rakits teach him a lesson in life:

But here are two dry rakitas

They lie in exhaustion ...

They were not killed by an evil storm, -

The evil man killed them.

They broke and branches,

As if with strong hands,

Having fallen, they rested on the ground;

And, saying goodbye to heaven,

Since then they have looked down sadly.

But the death of Rakita is age old

Could not survive from the world:

Let's go young shoots

From a split trunk. (Zhemchuzhnikov, 1910, 153)
Rakits remind by their appearance of the eternal guarantee of life and death in nature, where the latter is only a stage, albeit a sad one, but not the limit:

Oh, how powerless before death,

I'm glad for my rakita!

And it crumples to me: looking sweetly,

And these also say;

They tell me, showing both

A hollow burnt inside:

A hollow burnt inside:

"In spite of cruel malice,

We are all still living, look! "

Poor fellows! They look like me.

They'd better wither slowly

If only they could see God's light,

If only to die later.

(Zhemchuzhnikov, 1910, 152)

But even here the path of the lyrical hero does not end, he continues his journey along the high road in the third poem of the cycle:

I've been walking for a long time - and before my eyes

The roads are all the same;

All the same, with variegated flowers,

Green carpet spreads. (Zhemchuzhnikov, 1910, 152)

Green carpet spreads.

However, external beauty does not distract from the thoughts of the heart and contemplation:

And what a silence!

As if paved with that

There was a road to be dumb

Silence reigned here. (Zhemchuzhnikov, 1910, 153)

Silence, the absence of a person also turn the road into a path, but any initiation path is not complete without trials. In the fourth poem of the cycle, the hero rests before the storm, before dark, in the fifth, he is awakened and warned by the appearance of a stray dog (the dog is connected, on the one hand, with the house, on the other, with the otherworld, it corresponds to the wolf (Gura, 1997, p. 176)), in the sixth - darkness overtakes him, which turns into Darkness:

Under a moonless sky covered with clouds, Along the overgrown, dug-out ruts I drive, but I don't see: a field or a ravine, With bells three in a tarantass step. (Zhemchuzhnikov, 1910, 155) 
The liminal position of the hero, which is set by his ignorance of where he is, is aggravated by the absence of a luminary above his head, Light, and he plunges into total Darkness:

Black road; black horses;

All items are black; all on a black background. Only spots are visible - and there are not many of them -

On the road itself il copen, il haystacks;

Yes, sometimes, having climbed an open hillock, You will meet the outline of an orphan-rakita ... (Zhemchuzhnikov, 1910, 155)

However, Darkness (here and there is a shadow) is apophatic, since light is born in it. According to the German Philosopher M. Heidegger, "the common opinion sees in the shadow only a lack of light ... the shadow is a clear, albeit impenetrable, evidence of a hidden glow" (Heidegger, 1993, p. 62) and such a symbol (place) of the glow can be a rakita ... Nothing is visible to the eye, you can only feel your state, being in the kingdom of the night, and again here the image of the rakita arises - as a guide, reminiscent of the eternal, which performs the functions of a ritual marker of space. Rakita in the night is the World Tree at world midnight, which must be reached by the cultural hero in order to be reborn in a new quality. The hero is alone on this path, his loneliness is ontological in nature:

I hear: they are going somewhere, a spring sound is close;

I see nothing but a black night.

With someone at a crossroads we are, not without fright,

Moved together, parted, not seeing each other. The kingdom of the black night, the kingdom of black earth ...

I would like to see the light! I would rather be at home! (Zhemchuzhnikov, 1910, 155)

A dangerous situation of "ontological loneliness of unrecognition" arises, when Bakhtin's dialogue between friend and foe is not carried out (Istomina, 2010, p. 69), but Zhemchuzhnikov's hero still seeks to find his home, in contrast, for example, to Pushkin's in "Winter Road", The plot of which is similar to the poem "Darkness":

Boring, sad ... Tomorrow, Nina,

Tomorrow returning to the darling,

I will forget by the fireplace

I will look in without looking. (Pushkin, 1977, p. 303)
According to Pushkin, the main character is quite abstract, the name Nina helps to create the image of a woman who is physically absent (Nenarokova, 2019, p. 27), the image of Nina is associated with the sphere of death (Dudareva, 2020).

\section{Conclusion}

Researchers rightly notice the diversity of road impressions in Zhemchuzhnikov's poetry: "Sometimes this is a description of pictures visible to the eye, sometimes it is a transfer of a person's feelings, his state of mind during a trip, often philosophical reflections related to road meetings and landscapes, and sometimes it is a metaphorical image - the road of life, the final transition from life to death. In the poetry of A. M. Zhemchuzhnikov there are numerous intersections with the literary tradition, with the image of the road in the verses of Russian classics" (Kapitonova, 2005, p. 42). But it is worth emphasizing once again that Zhemchuzhnikov's road turns ontologically into a path, it is not just a road to the village, it is a path - a road from Russian fairy tales and epics, where the hero learns the world around him, comprehends the cosmos of nature and finds his place in it. Gachev, describing the Russian national space, pays special attention to our flatness, to the aspiration of the Russian person into the distance, which is expressed in the concept of "path - road": "The path - road from the threshold to infinity horizontally across the plain is the Russian image of the world ..." (Gachev, 2008, p. 27). It is no coincidence that the lexeme "path" appears in the last poem of the cycle. Zhemchuzhnikov, whose hero traveled a long way from Moscow to the countryside and back, completes his "rural impressions" with such playful ease. The lyrical hero's guide, his faithful companion on this path is Rakita, lonely and close, understandable and mysterious. Russian folklore tradition, analyzing the last stanza, the image of "path - road". The appeal to folklore is fruitful, since A. M. Zhemchuzhnikov was well acquainted with oral folk art.

\section{Bibliographic references}

Abramova, E. I. (2019). Linguocultural potential of the dendronym Oak and the Anglo-Celtic symbolism of the oak. Philology and man, No. 3, pp. 66-81.

Agapkina, T.A. (2014). Symbols of trees in the traditional culture of the Slavs: willow, willow, rakita (genus Salix). Slavic Almanac. Issue 1-2. M.: Indrik. pp. 283 - 302. 


\section{AMAZONDA}

Dudareva, M.A. (2020). Apophatic reality in A. S. Pushkin's poem "Winter road": the image of an ideal beloved. Culture and civilization, T. 10 , No. $3^{\text {a }}$, S. 213-221.

Dudareva, M. A., \& Goeva, N. P. (2017). White willow in russian literature: Folklore "roots" of image. Journal of Social Studies Education Research, 8(3), pp. 291-299. https://files.eric.ed.gov/fulltext/EJ1162295.p df

Gachev, G. D. (2008). The mentality of the peoples of the world. - M.: Algorithm; Eksmo. 544 p. https://litgu.ru/knigi/guman_nauki/127778mentalnosti-narodov-mira.html

Gorbunova, K.A. (2021). The plot about the gray wolf in Russian lullabies. Scientific Forum of Students. [Electronic resource]. Access mode:

http://www.scienceforum.ru/2013/18/5298 (date of access: 28.08.2021).

Gura, A. V. (1997). Bear // Symbols of animals in the Slavic folk tradition. - M.: Indrik, pp. 159-177.

https://inslav.ru/publication/gura-vsimvolika-zhivotnyh-v-slavyanskoynarodnoy-tradicii-m-1997

Heidegger, M. (1993). Time and Being: Articles and Speeches. M.: Respublika, 447 p.

Isakova, A.A. (2011). Composition, structure and functions of the lexical-semantic group "dendronyms" in the literary text of the early XX century (based on the poetry of the Silver Age): (author. dis. ... Candidate of philosophy science), State University named after Academician I.G. Petrovsky", Kursk, 23 https://www.dissercat.com/content/sostav- struktura-i-funktsii-leksiko-semanticheskoigruppy-dendronimy-v-khudozhestvennomteks

Istomina, O.B. (2010). Dialogue in the context of the disposition "friend or foe". Bulletin of the Buryat State University, No. 6, pp. 66-70. https://cyberleninka.ru/article/n/dialog-vusloviyah-dispozitsii-svoy-chuzhoy

Kapitonova, N.A. (2005). Lyrics of A. M. Zhemchuzhnikov: Problems and Poetics (dis. ... Cand. Philol). Michurinsk State Agrarian University, Michurinsk, 229 p. https://www.dissercat.com/content/lirikaam-zhemchuzhnikova-problematika-ipoetika

Nenarokova, M. R. (2019). Pushkin, A. S. "The Winter Road": The Poem's Reception in the English-Speaking World through the Mirror of Close Reading. Philological Class, $\mathrm{N}^{\circ}$ 2(56), pp. 22-30.

Pushkin, A.S. (1977). Sobr. Cit.: in 10 volumes, L.: Science, T. $2 . \quad$ http://febweb.ru/feb/pushkin/texts/push10/d00.html?c $\mathrm{md}=1 \& \mathrm{dscr}=1$

Syanova, E.I. (2010). The flora in the onomastic picture of the world of the dialect carrier (based on mixed Russian and Ukrainian dialects of the Voronezh region) Ethnobotany: plants in language and culture. SPb.: Science, S. 78-99.

Yesenin, S. A. (1997). Keys of Mary. Sobr. cit.: in 7 volumes. M.: Science; Voice, T. 5, pp. 186-213. http://febweb.ru/feb/esenin/default.asp

Zhemchuzhnikov, A. M. (1910). Rural impressions and pictures. Poems: in 2 volumes. St. Petersburg: Printing house of M. M. Stasyulevich, T. 1, pp. 150-160. 